It is important to note that Shakespeare always provides the evidence for the defence as well as for the prosecution. The ambivalence of his art enables directors to pick and choose interpretations either to satisfy the expectations of the age or to confound them. Olivier's film of Henry $V$ in 1944 was inevitably patriotic, but like Branagh's more realistic one in 1990, it was based securely on the text. Sometimes there are surprises. Kozintsev's great film of King Lear coming from an officially atheist regime was essentially Christian in spirit, whereas Brook's film of the same year belonged clearly to the Theatre of the Absurd.

Dr. González's radical position involves the repudiation of a merely literary Shakespeare, embalmed in Quartos and Folios, demanding worship and orthodoxy. Instead he wants a fluid Shakespeare based on performances. I would agree that this is better suited to an actor and playwright who belonged to the most popular company of his time, than the god-like figure almost divorced from the practical job to which he gave his life. My only doubt is caused by the fact that although there are dozens of legitimate interpretations of each of the plays, there are scores of illegitimate ones. I am reminded of a production at Stratford at which I sat next to a theologian of my acquaintance. We both thought the production was unforgiveably silly, and I asked my friend if he would give me absolution if I were to shoot the director. He replied: "Plenary absolution."

Dr. González discusses many of the plays from his radical standpoint. There is, for example, a fine analysis of the abdication scene in Richard II and of Bolingbroke's sense of guilt. Perhaps the Shrew's submission is best played ironically, as it was by Edith Evans and other great actresses. It has always been recognized that the heroines of the comedies are greatly superior to the young men they eventually marry, as the young women in Spanish comedies of the Golden Age far outshine the men. Shakespeare, we may suppose, deplored the macho characteristics of his society, although, I suspect, Dr. González sometimes overstresses the feminist outlook. He laments that Isabella in Measure for Measure is forced to marry the Duke; but I have seen one production in which she declines his hand. Yet, if she admired and loved him as her spiritual adviser, it would surely be possible for the pious heroine to transfer her affections to Vincentio when he turns out to be the ruler. They are well matched.

Kenneth Muir

\title{
Rose Petterson. Nadine Gordimer's One Story of a State Apart. Stockholm: Uppsala University, 1995.
}

In her detailed study of Gordimer's work, Nadine Gordimer's One Story of a State Apart, Rose Petterson seeks to establish two main themes which she can interrelate: the political system of apartheid in South Africa and the feminist perspective. With these premises, the five chapters of her book cover different variations on these themes, illustrated with an analysis of her novels which very wisely does not follow a chronological order.

Gordimer's openly political involvement with apartheid in her creative writing is noticeable from her earliest work. Most of her fellow-members in the privileged white 
society of South Africa were born and bred with apartheid and accepted it as part of their lifestyle. Gordimer saw the total irrationality of discrimination, was deeply affected by the personal predicament of so many human beings trapped within its inescapable web and reflected it in her work. As she progressed from the earlier creative period to the more recent novels her perception increased and her critical position became fiercer.

The "liberal humanist perspective," as Rose Petterson dubs it, of The Lying Days (1953) and A World of Strangers (1958), contained a conciliatory outlook together with a just perceptible patronizing attitude towards the black population. This would give way to a leftist radicalism which was already developed in The Conservationist (1974) and would eventually lead her to believe that a violent revolution against whites was the only solution to the racial problem.

Rose Petterson carries out a balanced analysis of this ideological evolution and the effect it has in Gordimer's novels, without showing any preferences to either period of her writing. Contemporary criticism was less calm. Tony Morphet, for instance, began suddenly to detect, as Petterson reports, "certain "flaws"' in Gordimer's fiction, coming to the conclusion that she runs the risk of being lured into "facile collusion with the international democratic left and its literary establishment." Petterson's astonishment at this statement is understandable. In her introduction we read: "Through the years, Gordimer has been criticised for the apparently cold and dispassionate approach she employs in her fiction." It is this fact, her narrative objectivity, the lack of Manicheanism, that has proved one of Gordimer's most effective devices in capturing the attention of the international reader and thus focusing his gaze on the ideologically remote world of apartheid.

For the home market, the South African reader, it was an opportunity to study, as Brenda Cooper has said, "an exile literature written from within the country." Petterson adds that Gordimer was able to "present all South Africans with a mirror image."

The second main theme in this doctoral thesis is the feminist perspective, more specifically the role of the white woman within an apartheid society. In Gordimer's novels, says Petterson, "although the South African woman enjoys certain privileges because of being white, her role nevertheless remains one of subservience in relation to the white male." Petterson analyses the attitudes of several female characters from the novels in their relationships (family, social, ideological, sexual, etc.) to men. This focusing would probably be in direct conflict with Gordimer's own pronouncement on feminism, specially if we consider statements such as: "It's not something I would pursue as a separate issue." or "I don't think it matters a damn what sex a writer is" (shades of Virginia Woolf?). But the simple fact of her nonconformism, albeit mainly political, makes very tempting a feminist reading of Gordimer despite her own words, which lead Dorothy Driver to define them as "reactionary statements."

Rose Petterson's analysis is more restrained. Her intertextual approach ranges from the strictly literary-among others Yeats and Eliot, not Woolf-to the sexual-political psychoanalysis of Wilhelm Reich and the racial theories of Frantz Fanon. Among other issues, she analyses the effect of political implications on family ties, which usually have devastating consequences. Gordimer seems not to think highly of family relationships anyway, specially between mothers and daughters, leading Petterson to state that " [i]t is 
obvious that reflections of mothers in the early narratives reveal to what extent Gordimer's childhood experiences influenced and shaped the telling of her one story." A biographical approach is also very tempting. Petterson, fortunately, allows it only six pages.

To sum up, this book covers all of Gordimer's work and it encourages you to seek and find the novels not yet read. The gradual disappearance of South African apartheid, paradoxically, benefits their reading, as the reader can now pay greater attention to their strictly literary value. And, as we can appreciate in the many excerpts Petterson includes in her book, there is a lot to look forward to.

John D. Sanderson 